\title{
HUBUNGAN ANTAR-KOMPONEN MENUJU SEKOLAH BERMUTU Djohar Maknun
}

\section{A. Hubungan Antar-komponen Model Penggambaran Sekolah Bermutu}

Contoh model yang digambarkan ini adalah pada mata pelajaran Biologi, pada level daerah tingkat II (Kabupaten/Kotamadya) yang pada era otonomi daerah, pengelolaan pendidikan menjadi tanggung jawab pemerintah daerah tingkat II yang dalam hal ini secara operasional dilaksanakan oleh Departemen Pendidikan Nasional (Kantor Dinas) Kabupaten/Kota. Intinya ketika menjadikan sekolah bermutu proses supervisi pendidikan harus berjalan dengan baik pada tingkat sekolah dan semua komponen yang terlibat, sehingga menghasilkan prestasi belajar siswa yang unggul (kognitif, afektif dan psikomotorik).

Komponen-komponen yang terlibat dalam organisasi ini adalah Kebijakan Nasional, Kepala Dinas Diknas Kabupaten/Kota, pengawas (supervisor) Kabupaten/Kota, kepala sekolah, guru-guru, siswa, dan masyarakat yang diwakili oleh Dewan Sekolah (dulu BP3). Juga melibatkan staf lainnya seperti petugas laboran, teknisi, dan staf administrasi sebagai unit pelayanan kegiatan proses belajar-mengajar (PBM) dan evaluasinya. Komponenkomponen tersebut membentuk suatu sistem pengembangan sekolah untuk meningkatkan mutu layanan pembelajaran sehingga akan terwujud peningkatan mutu PBM yang pada gilirannya akan mewujudkan hasil /prestasi belajar siswa yang tinggi (out put) baik kognitif maupun non-kognitif, dan out comenya adalah lulusan yang handal.

Secara skematis keterkaitan antar komponen dapat dilihat pada Gambar 4. Gambaran, fungsi dari masing-masing komponen dapat diuraikan sebagai berikut :

1) Kepala Dinas Diknas Kabupaten/Kota

Kepala Dinas Diknas Kabupaten/Kota sebagai pejabat penyelenggara pendidikan tertinggi di Kabupaten/Kota berfungsi sebagai koordinator supervisi yang sekaligus merupakan manajer supervisi di tingkat Kabupaten/Kota. Perannya mengkoordinir, mengarahkan dan mengontrol seluruh komponen yang ada dalam sistem, seperti kepala sekolah, guru, KKKS, KKPS dan MGMP.

Kepala dinas berperan untuk menciptakan iklim yang memungkinkan terjadinya proses pembaharuan diri (self-renewal) pada tingkat kelembagaan sekolah. Kantor Dinas Kabupaten/Kota harus mendukung program-program sekolah yang bertujuan untuk meningkatkan mutu pembelajaran dengan memanfaatkan sumber daya pendidikan yang diakomodasi sendiri serta menghilangkan penerapan birokrasi yang kaku dan hierarkis. 


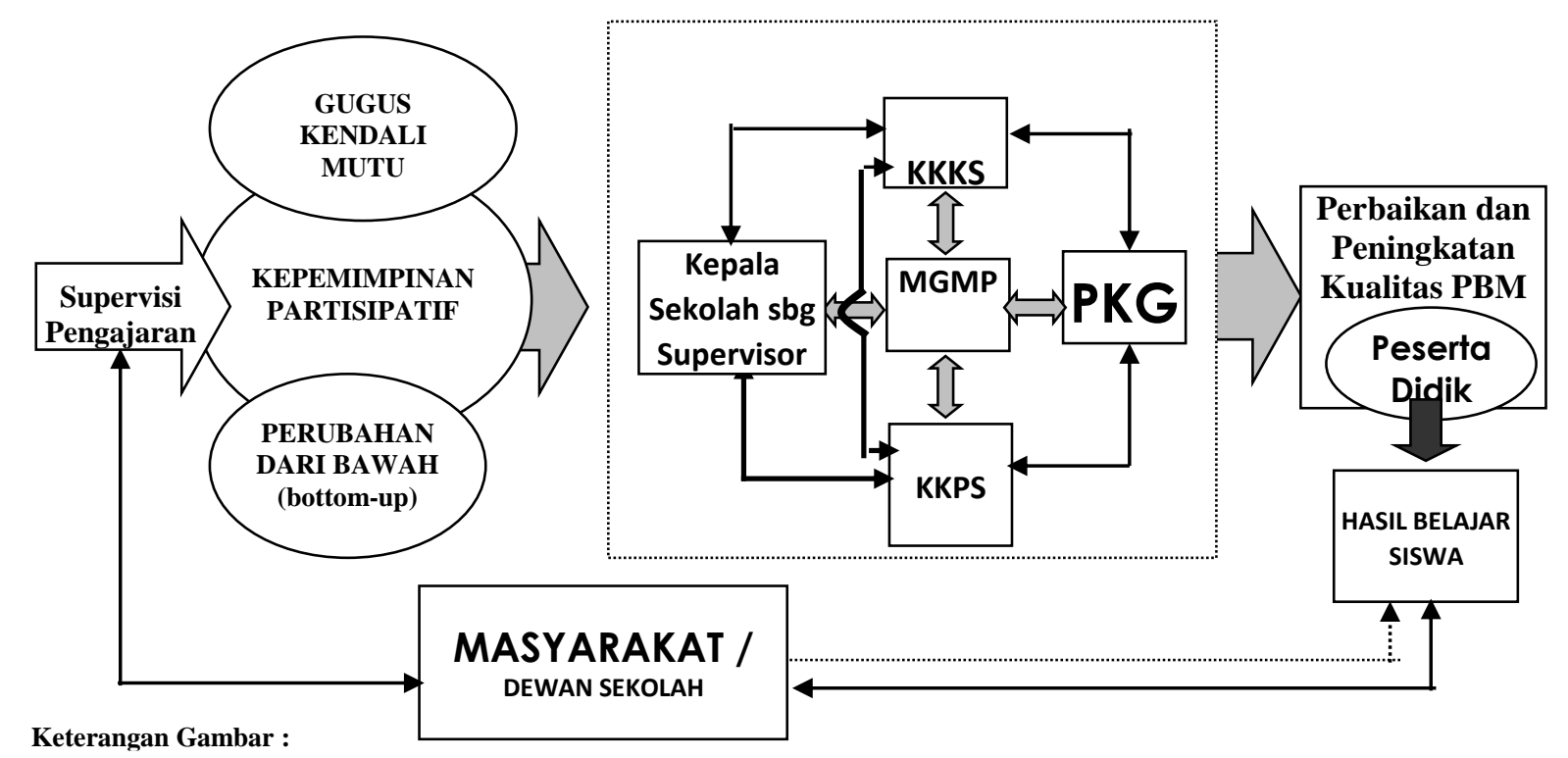

Alur Kegiatan

$\Leftrightarrow$ Garis Konsultasi

Garis Pengawasan

1) Pengawas Umum dan Pengawas Bidang Studi

Para pengawas merupakan staf supervisi yang diberi kewenangan oleh Kepala Dinas Kabupaten/Kota untuk melakukan supervisi kepada para guru. Para pengawas menjabarkan tugas-tugas supervisi yang telah direncanakan untuk masing-masing sekolah sesuai dengan situasi dan kondisi sekolah yang bersangkutan, dan juga masalah-masalah spesifik yang sedang dihadapi oleh guru-guru di masing-masing sekolah.

Pengawas melakukan tugas pembinaan dan sekaligus pengawasan terhadap guru dalam suasana demokratis, dialogis dan kemitraan. Untuk itu diperlukan suasana keterbukaan antara para pengawas dengan para guru. Pengawas berfungsi menciptakan kondisi yang kondusif untuk terjadinya pembaharuan diri (self-renewal) pada para guru. Pengawas bidang studi di samping membina aspek metodologi yang bersifat umum juga membina metodologi khusus pembelajaran . Misalnya pendekatan keterampilan proses. Inquiri, eksperimen, demonstrasi, pendekatan lingkungan dan sebagainya yang biasa digunakan dalam pembelajaran.

Pengawas bidang studi juga berfungsi untuk membina guru dari aspek penguasaan materi pelajaran, misalnya membenahi miskonsepsi guru tentang konsep-konsep dan memberikan pengayaan materi melalui supervisi klinis. Dalam melaksanakan fungsi pengawasan dan pembinaan kepada guru, pengawas berkoordinasi dan bekerjasama dengan guru-guru yang tergabung dalam wadah MGMP. 
Dalam kerjasama ini pengawas menjaga sinkronisasi antara kegiatan guru dengan kegiatan mereka di sanggar MGMP. Dengan cara demikian, kegiatan supervisi akan sinkron dengan kegiatan MGMP. Para guru inti di MGMP merupakan partner kerja para pengawas. Kerjasama antara pengawas dengan kelompok kerja pengawas juga sangat penting dilakukan. Dengan kerjasama ini, mereka akan dapat saling tukar-menukar informasi dan pengalaman dari ragam temuan mereka dilapangan.

2) Kepala Sekolah

Kepala sekolah, di samping sebagai pejabat struktural dan administrasi di sekolah juga berfungsi sebagai supervisor yang melakukan pengawasan dan pembinaan terhadap kerja guru dan staf sekolah lainnya. Oleh karena itu, kepala sekolah akan banyak mewarnai perkembangan sekolah yang dipimpinnya. Sebagai seorang supervisor dan pejabat strukrutal, kepala sekolah harus menekankan pentingnya memimpin sekolah agar guru merasa betah berada dalam tim kerja yang efektif, merasa senang dengan pekerjaannya, merasa meraih sesuatu yang berguna dalam pekerjaannya.

Kepala sekolah hendaknya tidak hanya pandai memerintah, lebih dari itu sebagai manajer, kepala sekolah juga memegang peranan penting dalam menciptakan hubungan baik antara sekolah dan masyarakat. Kepala sekolah dituntut untuk senantiasa berusaha membina dan meningkatkan hubungan kerja sama yang baik antara sekolah dan masyarakat guna mewujudkan sekolah yang efektif dan efisien (Deden N.K., 2003).

3) Tugas Guru

Guru merupakan anggota masyarakat yang mengabdikan dirinya sebagai agen pembaharuan, pemimpin belajar dan fasilitator dalam pembelajaran pada pendidikan formal, bertanggung jawab secara profesional dalam menjamin mutu pendidikan demi tercapainya hasil belajar peserta didik. Untuk itu guru perlu meningkatkan kompetensinya secara terus menerus sehingga dapat menjadi contoh masyarakat dan peserta didiknya.

Guru yang profesional memiliki ciri-ciri menguasai substansi kajian yang mendalam serta dapat melaksanakan pembelajaran yang mendidik, berkepribadian, dan memiliki komitmen dan perhatian terhadap perkembangan peserta didik. Untuk memenuhi hal tersebut, guru perlu standar-standar kemampuan dalam kapasitasnya sebagai pengajar. Semua guru harus memahami dulu pengetahuan dasar untuk tugas mengajar.

Siregar (1999) mengidentifikasi tujuh macam pengetahuan dasar tugas mengajar yang digambarkan dengan model seperti pada Gambar 2. Jika seorang guru sudah memahami ketujuh pengetahuan dasar tersebut dan dapat memadukannya dalam suatu proses pembelajaran diharapkan akan menghasilkan pembelajaran yang bermutu. Di antara semua 
pengetahuan ini yang paling penting dalam pembelajaran adalah pengetahuan materi subyek dan pengetahuan pedagogi umum yang digabungkan menjadi pengetahuan konten pedagogi.

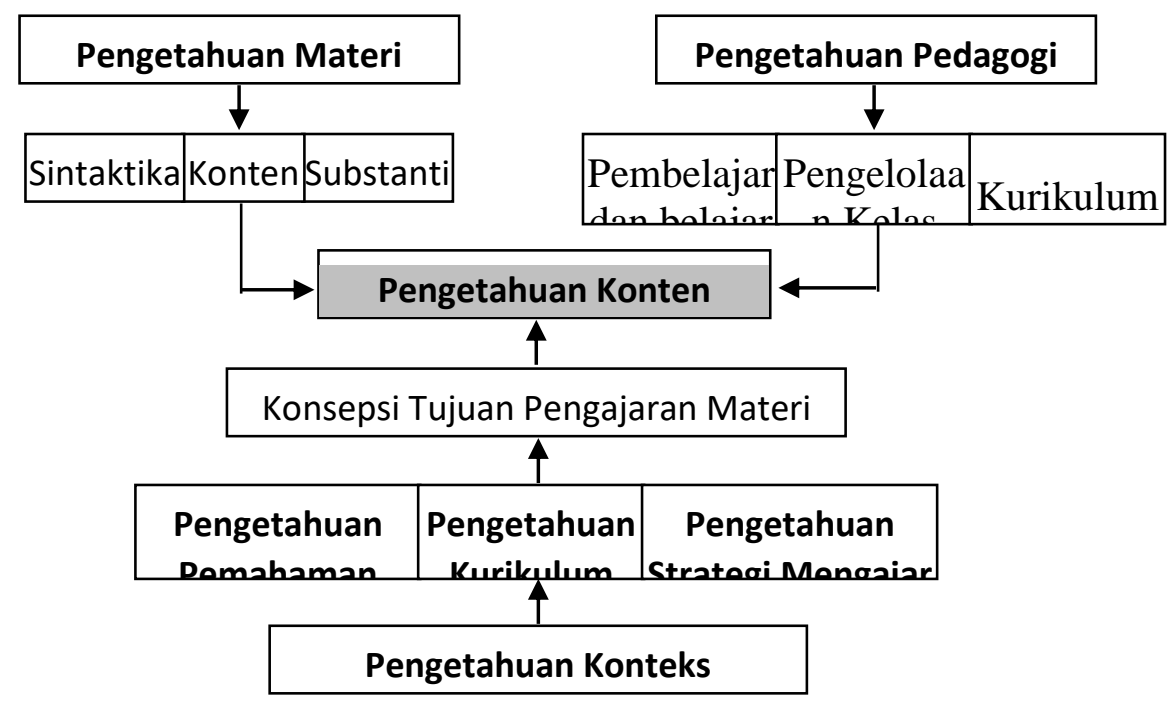

Gambar 2. Diagram pengetahuan dasar tugas mengajar

\section{4) MGMP, KKKS dan KKPS}

Musyawarah Guru Mata Pelajaran (MGMP) adalah wadah kegiatan profesional guru mata pelajaran sejenis sanggar. Kegiatan-kegiatan MGMP pada dasarnya bertujuan untuk : 1) menumbuhkan kegairahan guru untuk meningkatkan kemampuan dan keterampilan dalam mempersiapkan, melaksanakan, dan mengevaluasi program kegiatan belajar mengajar dalam rangka meningkatkan keyakinan diri sebagai guru. 2) menyetarakan kemampuan dan kemahiran guru dalam melaksanakan belajar-mengajar sehingga dapat menunjang usaha peningkatan dan pemerataan mutu pendidikan. 3) mendiskusikan permasalahan yang dihadapi oleh guru dalam melaksanakan tugasnya sehari-hari dan mencari cara penyelesaian yang sesuai dengan karakteristik mata pelajaran, guru, kondisi sekolah dan lingkungan. 4) membantu guru memperoleh informasi teknis edukatif yang berkaitan dengan kegiatan keilmuan dan IPTEK, kegiatan pelaksanaan kurikulum, metodologi sistem evaluasi sesuai dengan mata pelajaran bersangkutan, 5) saling berbagi informasi dan pengalaman dalam menyesuaikan dengan perkembangan ilmu dan teknologi.

\section{5) Pusat Kegiatan Guru (PKG)}

PKG merupakan wadah guru, kepala sekolah dan pengawas sekolah yang pada waktu tertentu dapat bertemu/bersama-sama untuk memikirkan, membahas dan memecahkan 
masalah secara bersama untuk kepentingan semua pihak, yaitu memperbaiki kualitas proses belajar mengajar. Fokus masalah yang dibahas di PKG adalah bagaimana mengimplementasikan kurikulum dengan sebaik-baiknya. Dalam arti bagaimana menyempurnakan dan memperbaiki mutu proses belajar-mengajar. Keterlibatan pengawas sekolah, kepala sekolah di PKG tidak lepas dari peranan mereka sehingga supervisor pengajaran selalu dituntut untuk dapat membantu dan membimbing guru meningkatkan peran profesionalnya.

\section{6) Peran Siswa dalam Supervisi}

Siswa sebagai subyek belajar memegang peranan penting dalam PBM. Hasil pembelajaran akan sangat ditentukan sejauhmana siswa mau belajar. Dalam proses pembelajaran, motivasi dan usaha keras pebelajar untuk mencapai prestasi yang tinggi, mau berkorban baik waktu dan tenaga secara utuh dan optimum. Pengorbanan yang dimaksudkan adalah bersedia meninggalkan kegiatan lain yang disenangi demi untuk belajar di sekolah. Faktor motivasi, usaha keras dan kesiapan siswa seringkali diabaikan oleh birokrat pendidikan, kepala sekolah, dan guru.

Dalam konteks supervisi akademis siswa adalah customer pertama yang ikut menentukan kualitas hasil belajarnya. Mereka juga merupakan sumber informasi yang akurat untuk menilai penampilan guru di kelas. Pola interaksi yang terjadi antara siswa dengan guru mencerminkan bagaimana kualitas proses belajar-mengajar terjadi. Kadar obyektivitas yang ditunjukkan oleh siswa dalam berinteraksi akan menentukan tingkat obyektivitas data yang diperoleh para supervisor maupun guru dalam upaya perbaikan kualitas proses belajar-mengajar (PBM).

7) Peran Leboran, Teknisi, Petugas Perpustakaan dan Staf Administrasi

Sukses tidaknya guru-guru Biologi dalam menyelenggarakan PBM juga ditentukan oleh dukungan yang diberikan oleh staf sekolah lainnya seperti laboran, teknisi, petugas perpustakaan, dan juga pegawai administrasi lainnya. Guru tidak dapat melakukan tugas mengajar dengan pendekatan keterampilan proses bila laboran atau teknisi tidak menyiapkan peralatan yang diperlukan dalam percobaan yang akan dilakukan di laboratorium. Demikian pula mengenai perpustakaan, guru tidak mungkin menugaskan siswanya untuk mncari informasi di perpustakan sekolah bila petugas perpustakaan tidak menyediakan layanan sebagaimana mestinya.

Guru tidak bisa bekerja dengan tenang manakala masih memikirkan urusan administrasi yang berkaitan dengan peningkatan jenjang kepangkatan karena pegawai adminstrasi tidak menyediakan layanan yang baik. Dengan demikian peran laboran, teknisi, 
petugas perpustakaan dan pegawai administrasi sebagai unit pelayanan tidak kalah pentingnya dalam upaya meningkatkan kualitas PBM. Dalam model supervisi pendidikan berbasis manajemen mutu terpadu, kepala sekolah dan pengawas walaupun menekankan pada pengembangan profesionalisme guru, juga harus melakukan pengawasan, koordinasi dan pembinaan terhadap unit-unit pelayanan ini agar mereka dapat memberikan pelayanan yang sebaik-baiknya. Adanya komitmen dari masing-masing unit untuk memberikan pelayanan terbaik, niscaya memberikan kualitas PBM seperti yang telah direncanakan (mudah dicapai).

8) Peran Informasi dan Komunikasi dalam Hubungan Sekolah dan Masyarakat

Untuk dapat meningkatkan dukungan masyarakat terhadap program sekolah dalam rangka mengamankan core bussiness pendidikan, diperlukan upaya sungguh-sungguh dalam penyampaian informasi tentang sekolah (fakta, pikiran, perasaan, kebutuhan, sasaran) kepada masyarakat. Informasi ini dapat bertalian dengan kemajuan dan prestasi siswa (peserta didik), perkembangan baru dalam kurikulum dan metode pengajaran, cara baru dalam melaporkan kemajuan siswa, kesehatan siswa, program penataran guru-guru, perluasan gedung sekolah, perkembangan pengajaran di sekolah-sekolah, program kegiatan siswa, dan masih banyak lagi hal lain yang penting diketahui oleh orang tua siswa dan masyarakat. (Deden N. K. , 2003).

Selama ini peran masyarakat terhadap sekolah belum begitu tampak. Orang tua siswa yang tergabung dalam organisasi BP3 hanya diperhatian pada waktu sekolah membutuhkan bantuan dana sumbangan BP3 saja. Dalam hal kontrol mutu pendidikan hampir tidak pernah dilibatkan. Masyarakat adalah salah satu customer pendidikan dimana mereka juga ikut menentukan kualitas pendidikan. Tanpa bantuan dari orang tua siswa dalam arti memenuhi segala kebutuhan yang diperlukan putra putrinya dalam PBM, maka sulit memperoleh kualitas yang diharapkan.

\section{Ukuran Keberhasilan/Indikator Keberhasilan}

Secara umum keberhasilan implementasi pengembangan model ini dapat dilihat dari ketercapaian tujuan, yakni mengoptimalkan peran dan fungsi individu-individu atau kelompok-kelompok, membantu guru dalam kegiatan proses belajar mengajar agar mereka dapat berkembang secara profesional, terciptanya kondisi kerja yang harmonis dalam hubungan kemitraan antara kepala sekolah, guru, siswa, supervisor (pengawas) dan staf sekolah lainnya, dan meningkatnya keterlibatan dan tanggung jawab masyarakat terhadap 
mutu pendidikan yang semuanya mengarah pada meningkatnya kualitas proses dan hasil belajar siswa. Oleh karena itu ukuran keberhasilan model dapat dirumuskan sebagai berikut :

Tabel 1. Ciri dan indikator keberhasilan

\begin{tabular}{|c|c|}
\hline CIRI-CIRI & INDIKATOR \\
\hline $\begin{array}{l}\text { Tujuan sekolah dinyatakan secara } \\
\text { jelas dan spesifik }\end{array}$ & $\begin{array}{l}\text { Tujuan Sekolah : } \\
>\text { Dinyatakan secara jelas } \\
>\quad \text { Digunakan untuk pengambilan keputusan } \\
>\quad \text { Dipahami oleh siswa, guru dan staf }\end{array}$ \\
\hline $\begin{array}{l}\text { Pelaksanan kepemimpinan pendidikan } \\
\text { yang kuat oleh kepala sekolah }\end{array}$ & $\begin{array}{ll}\text { Kepala Sekolah : } \\
> & \text { Bisa dihubungi dengan mudah } \\
> & \text { Bersikap rsponsif kepada guru, staf dan siswa } \\
> & \text { Melaksanakan kepemimpinan yang terfokus pada pembelajaran }\end{array}$ \\
\hline Ekspektasi Guru dan Staf, Tinggi & $\begin{array}{l}\text { Guru dan Staf: } \\
>\text { Yakin bahwa semua siswa bisa belajar dan berprestasi } \\
>\quad \text { Menekankan pada hasil akademis } \\
>\quad \text { Memandang guru sebagai penentu terpenting bagi keberhasilan } \\
\text { siswa }\end{array}$ \\
\hline $\begin{array}{l}\text { Ada kerjasama kemitraan antara } \\
\text { sekolah, orang tua dan masyarakat }\end{array}$ & $\begin{array}{ll}\text { Sekolah : } \\
>\quad \text { Komunikasi secara positif dengan orang tua } \\
>\quad \text { Memelihara jaringan \& dukungan orang tua } \\
>\quad \text { Orang tua dan masyarakat brbagi tanggug jawab untuk } \\
\text { menegakka disiplin dan mempertahankan keberhasilan }\end{array}$ \\
\hline $\begin{array}{l}\text { Adanya iklim positif dan kondusif } \\
\text { bagi siswa untuk belajar }\end{array}$ & $\begin{array}{l}\text { Sekolah: } \\
>\quad \text { Rapih, bersih dan aman secara fisik } \\
>\quad \text { Dipelihara dengan baik } \\
>\quad \text { Memberi penghargaan kepada yang berprestasi } \\
\text { Siswa : } \\
>\text { Memberi penguatan terhadap prilaku positif siswa } \\
>\text { Mengerjakan tugas tepat waktu }\end{array}$ \\
\hline $\begin{array}{l}\text { Adanya iklim positif dan kondusif } \\
\text { bagi guru untuk mengajar }\end{array}$ & $\begin{array}{ll}\text { Sekolah: } \\
> & \text { Menyediakan tempat atau fasilitas bagi guru untuk bekerja } \\
> & \text { Memberikan kesempatan dan menyediakan dana bagi guru untuk } \\
& \text { meningkatkan profesionalisme mlalui kegiatan seminar, } \\
& \text { penataran, penelitian tindakan kelas } \\
> & \text { Memberikan penghargaan kepada guru yang berprestasi } \\
> & \text { Tidak memberikan beban mengajar melebihi standar yang } \\
& \text { ditetapkan } \\
\text { Guru : } \\
>\text { Bekerja secara profesional dan mentaati aturan-aturan yang ada. } \\
>\text { Melaksanakan Tugas/kewajiban tepat waktu }\end{array}$ \\
\hline
\end{tabular}

\begin{tabular}{|c|c|}
\hline CIRI-CIRI & INDIKATOR \\
\hline Kemajuan siswa sering dimonitor & $\begin{array}{l}\text { Guru memberi siswa: } \\
>\quad \text { Tugas yang tepat } \\
>\quad \text { Umpan balik segera/cepat } \\
>\quad \text { Kemampuan berpartisipasi di kelas secara optimal } \\
>\quad \text { Penilaian hasil belajar dari barbagai segi }\end{array}$ \\
\hline $\begin{array}{l}\text { Menekankan kepada keberhasilan } \\
\text { siswa dalam mencapai keterampilan } \\
\text { aktivitas yang esensial }\end{array}$ & $\begin{array}{l}\text { Siswa: } \\
\text { Melakukan hal yang terbaik untuk hasil belajar yang optimal, } \\
\text { baik yang bersifat akademis maupun non akademis } \\
\text { Kepala Sekolah: } \\
\text { Menunjukkan komitmen dalam mendukung program } \\
\text { keterampilan sensial } \\
\text { Guru } \\
>\quad \text { Menerima bahan yang memadai untuk mengajarkan keterampilan } \\
\quad \text { yang esensial }\end{array}$ \\
\hline Komitmen yang tinggi dari SDM & Guru: \\
\hline
\end{tabular}




\begin{tabular}{|l|l|}
\hline sekolah terhadap program pendidikan & $>$ Membantu merumuskan dan melaksanakan pengembangan \\
& Staf: \\
& $>$ Memperkuat dan mendukung kebijakan sekolah dan pemerintah \\
& $>$ daerahj \\
\hline
\end{tabular}

Sumber : Diadopsi dan dimodifikasi dari Taylor (dalam Satori, 2001).

\section{Perubahan Model Supervisi Mutu Pendidikan}

Faktor-faktor yang mempengaruhi efektivitas, implementasi model ini, di antaranya : (1) karakteristik guru dan pengawas, (2) struktur sosial budaya setempat, (3) resistensi terhadap pembaharuan, (4) dukungan kondisi daerah, (5) dukungan kepemimpinan pendidikan di suatu kota/ wilayah, (6) sinergitas semua stakeholders pendidikan. Faktorfaktor ini perlu dikaji dan diperhatikan dalam kaitannya dengan implementasi model supervisi pendidikan.

Pengembangan model supervisi pendidikan dalam kerangka menyempurnakan standar program supervisi akademik, mencakup perubahan dalam memberikan tekanan untuk program-program pembelajaran biologi di SMA. Perubahan tersebut disajikan pada Tabel 3.

Tabel 2. Perubahan model program supervisi pendidikan

\begin{tabular}{|c|c|}
\hline KURANGI PENEKANAN PADA & LEBIH DITEKANKAN PADA \\
\hline $\begin{array}{l}\text { Pengembangan program pada tingkat atau jenjang } \\
\text { berbeda saling bebas satu sama lain }\end{array}$ & Koordinasi pengembangan program lintas jenjang \\
\hline $\begin{array}{l}\text { Penilaian tidak berhubungan dengan kurikulum dan } \\
\text { kegiatan mengajar }\end{array}$ & $\begin{array}{l}\text { Menyesuaikan kurikulum, kegiatan, mengajar dan } \\
\text { penilaian }\end{array}$ \\
\hline Tetap mengalokasikan sumber pada model & $\begin{array}{l}\text { Alokasi sumber yang diperlukan yang sesuai dengan } \\
\text { program }\end{array}$ \\
\hline $\begin{array}{l}\text { Kurikuklum dijalankan dari standar dan dengan } \\
\text { ceramah }\end{array}$ & $\begin{array}{l}\text { Kurikulum yang mendukung standar-standar dan } \\
\text { memuat berbagai komponen, seperti lab yang } \\
\text { menekankan inkuiri dan lapangan }\end{array}$ \\
\hline Meliputi informasi yang luas tetapi tak berhubungan & $\begin{array}{l}\text { Kurikulum memuat gejala yang berhubungan dengan } \\
\text { isi yang ditemukan siswa dalam kehidupan sehari-hari }\end{array}$ \\
\hline Mata pelajaran biologi terisolasi dari subyek lain & $\begin{array}{l}\text { Menghubungkan mata pelajaran biologi dengan } \\
\text { subyek sekolah lainnya, seperti matematika, IPA, IPS, } \\
\text { sejarah, dll }\end{array}$ \\
\hline $\begin{array}{l}\text { Kesempatan belajar yang menyenangkan } \\
\text { kelompok siswa }\end{array}$ & $\begin{array}{l}\text { Menyediakan kesempatan yang menantang untuk } \\
\text { semua siswa belajar }\end{array}$ \\
\hline $\begin{array}{lllll}\begin{array}{l}\text { Membatasi } \\
\text { administrasi }\end{array} & \text { keputusan } & \text { untuk } & \text { didengar } & \text { tenaga } \\
\end{array}$ & $\begin{array}{lllll}\begin{array}{l}\text { Melibatkan guru biologi dalam proses dengan } \\
\text { pendapat }\end{array} & & & \\
\end{array}$ \\
\hline Mempertahankan isolasi guru biologi & $\begin{array}{l}\text { Memperlakukan guru biologi sebagai tenaga } \\
\text { profesional yang kerjanya memerlukan kesempatan } \\
\text { untuk belajar terus menerus dan bekerja dalam } \\
\text { jaringan profesioanal }\end{array}$ \\
\hline Mendukung kompetensi & $\begin{array}{l}\text { Menunjukkan kolegalitas di antara guru biologi } \\
\text { sebagai satu tim untuk meningkatkan mutu } \\
\text { pembelajaran. }\end{array}$ \\
\hline Guru biologi sebagai pengikut & Guru biologi sebagai pengambil keputusan \\
\hline
\end{tabular}


Tabel 3. Perubahan model program supervisi sistem nasional

\begin{tabular}{|l|l|}
\hline \multicolumn{1}{|c|}{ KURANGI PENEKANAN PADA } & \multicolumn{1}{c|}{ LEBIH DITEKANKAN PADA } \\
\hline $\begin{array}{l}\text { Dukungan keuangan untuk mengembangkan } \\
\text { kurikulum baru belum menekankan pada standar- } \\
\text { standar }\end{array}$ & $\begin{array}{l}\text { Dukungan keuangan untuk mengembangkan } \\
\text { kurikulum baru menekankan pada standar-standar }\end{array}$ \\
\hline $\begin{array}{l}\text { Dukungan untuk kegiatan pengembangan profesional } \\
\text { hanya mempengaruhi sedikit guru }\end{array}$ & $\begin{array}{l}\text { Dukungan untuk kegiatan pengembangan profesional } \\
\text { disesuaikan dengan standar-standar dan menunujukan } \\
\text { perubahan dalam sistem yang luas }\end{array}$ \\
\hline $\begin{array}{l}\text { Lembaga bekerja secara independen pada berbagai } \\
\text { komponen pendidikan mata pelajaran biologi }\end{array}$ & $\begin{array}{l}\text { Koordinasi antar lembaga bertanggung jawab untuk } \\
\text { pendidikan mata pelajaran biologi }\end{array}$ \\
\hline $\begin{array}{l}\text { Dukungan untuk kegiatan dan program tak } \\
\text { berhubungan dengan reformasi berbasis standar- } \\
\text { standar }\end{array}$ & $\begin{array}{l}\text { Dukungan untuk kegiatan dan program haruslah } \\
\text { berhasil dalam mengimplementasikan standar nasional } \\
\text { pada jenjang provinsi dan kabupaten/ kota }\end{array}$ \\
\hline $\begin{array}{l}\text { Usaha-usaha pusat bebas dari jenjang propinsi dan } \\
\text { kabupaten/ kota }\end{array}$ & $\begin{array}{l}\text { Koordinasi upaya perbaikan pada tingkat pusat, } \\
\text { provinsi, dan kabupaten/ kota }\end{array}$ \\
\hline Proyek berjangka pendek & $\begin{array}{l}\text { Komitmen jangka panjang dari sumber-sumber untuk } \\
\text { memperbaiki mata pelajaran biologi }\end{array}$ \\
\hline
\end{tabular}

Sumber : Herawan (2004).

\section{Tabel 4. Perubahan model program supervisi sistem provinsi}

\begin{tabular}{|l|l|}
\hline \multicolumn{1}{|c|}{ KURANGI PENEKANAN PADA } & \multicolumn{1}{|c|}{ LEBIH DITEKANKAN PADA } \\
\hline $\begin{array}{l}\text { Inistiatif yang independen untuk memperbaiki } \\
\text { komponen dari pendidikan mata pelajaran biologi }\end{array}$ & $\begin{array}{l}\text { Kebersamaan dan koordinasi dari usaha-usaha } \\
\text { perbaikan }\end{array}$ \\
\hline $\begin{array}{l}\text { Bantuan untuk workshop dan program memiliki } \\
\text { hubungan yang kurang berarti dengan standar-standar }\end{array}$ & $\begin{array}{l}\text { Bantuan untuk pendidikan kurikulum dan pengajaran } \\
\text { berbasis pada standar-standar }\end{array}$ \\
\hline $\begin{array}{l}\text { Kerangka kerja, buku ajar, dan bahan-bahan } \\
\text { didasarkan pada kegiatan yang hanya secara margial } \\
\text { berhubungan dengan standar-standar }\end{array}$ & $\begin{array}{l}\text { Kerangka kerja, buku ajar, dan bahan-bahan } \\
\text { merupakan adopsi ukuran yang ditetapkan dengan } \\
\text { standar nasional dan provinsi }\end{array}$ \\
\hline $\begin{array}{l}\text { Penilaian diputuskan dari isi pendidikan mata } \\
\text { pelajaran biologi dalam paradigma lama }\end{array}$ & $\begin{array}{l}\text { Penilaian diputuskan dengan standar dan pandangan } \\
\text { yang diperluas tentang isi mata pelajaran biologi }\end{array}$ \\
\hline $\begin{array}{l}\text { Pendekatan yang digunakan adalah dalam pendidikan } \\
\text { guru }\end{array}$ & $\begin{array}{l}\text { Reformasi dari perguruan tinggi berkenaan dengan } \\
\text { pendidikan guru mencakup pedagogi disiplin yang } \\
\text { disesuaikan dengan standar-standar }\end{array}$ \\
\hline $\begin{array}{l}\text { Sertifikasi guru didasarkan pada persyaratan formal } \\
\text { dan riwayat pekerjaan }\end{array}$ & $\begin{array}{l}\text { Sertifikasi guru yang didasarkan pada pemahaman dan } \\
\text { kemampuan dalam mata pelajaran biologi dan } \\
\text { mengajar mata pelajaran biologi }\end{array}$ \\
\hline
\end{tabular}

Sumber : Herawan (2004).

\section{Tabel 5. Perubahan model program supervisi sistem kabupaten/ kota}

\begin{tabular}{|l|l|}
\hline \multicolumn{1}{|c|}{ KURANGI PENEKANAN PADA } & \multicolumn{1}{|c|}{ LEBIH DITEKANKAN PADA } \\
\hline $\begin{array}{l}\text { Workshop dalam jabatan adalah terlalu teknis dan } \\
\text { berjangka pendek }\end{array}$ & $\begin{array}{l}\text { Pengembangan profesional berkelanjutan untuk } \\
\text { membantu guru }\end{array}$ \\
\hline $\begin{array}{l}\text { Kebijakan tidak berhubungan dengan reformasi } \\
\text { berbasis standar-standar }\end{array}$ & $\begin{array}{l}\text { Kebijakan dirancang untuk mendukung perubahan } \\
\text { seperti dalam standar-standar }\end{array}$ \\
\hline $\begin{array}{l}\text { Pembelian buku ajar didasarkan pada pokok bahasan } \\
\text { tradisional }\end{array}$ & $\begin{array}{l}\text { Pembelian buku ajar atau adopsi kurikulum } \\
\text { disesuaikan dengan standar-standar dan pada } \\
\text { pendekatan konseptual untuk mengajar, termasuk } \\
\text { dukungan untuk material peragaaan }\end{array}$ \\
\hline $\begin{array}{l}\text { Tes dan penilaian yang distandarkan tidak } \\
\text { berhubungan dengan program dan praktek yang } \\
\text { berbasis standar-standar }\end{array}$ & $\begin{array}{l}\text { Penilaian disesuaikan dan diputuskan dengan standar- } \\
\text { standar }\end{array}$ \\
\hline $\begin{array}{l}\text { Administrasi yang menetukan apa yang akan } \\
\text { dilibatkan dalam meningkatkan pendidikan mata } \\
\text { pelajaran biologi }\end{array}$ & $\begin{array}{l}\text { Kepemimpinan guru dalam perbaikan pendidikan mata } \\
\text { pelajaran biologi }\end{array}$ \\
\hline $\begin{array}{l}\text { Otoritas pada jenjang yang lebih tinggi dari sistem } \\
\text { pendidikan }\end{array}$ & Otoritas untuk keputusan pada jenjang pelaksanaan \\
\hline $\begin{array}{l}\text { Komite sekolah tidak tahu menahu tentang program } \\
\text { pendidikan mata pelajaran biologi }\end{array}$ & $\begin{array}{l}\text { Dukungan komite sekolah untuk perbaikan } \\
\text { disesuaikan dengan standar-standar }\end{array}$ \\
\hline Kontrak lokal mengabaikan perubahan kurikulum, & Kontrak lokal mendukung perbaikan seperti ditentukan \\
\hline
\end{tabular}




\begin{tabular}{|l|l|}
\hline pengajaran dan penilaian & dalam standar-standar \\
\hline
\end{tabular}

Sumber : Herawan (2004).

Hasil dari paparan di atas, khususnya dalam mata pelajaran Biologi, dalam rangka meningkatkan sekolah bermutu, maka semua komponen harus terlibat secara profesional, sehingga akan berdampak positif pada prestasi belajar secara siswa secara kognitif, afektif dan psikomotorik.

Pengembangan program supervisi pendidikan Biologi dimasudkan untuk memperbaiki dan meningkatkan mutu dari proses dan hasil pembelajaran Biologi. Komponen langsung yang berpengaruh terhadap pembelajaran Biologi adalah guru Biologi. Oleh karena itu, pengembangan program supervisi pendidikan Biologi, mengutamakan sasarannya terhadap pengembangan profesi guru Biologi.

Pembinanaan dan bimbingan pada para guru pendidikan Biologi, akan efektif apabila kepala sekolah dan pengawas rumpun MIPA memiliki juga kompetensi dan kemampuan profesional dalam bidang yang disupervisinya, serta memiliki sejumlah kompetensi agar supervisor dapat menjalankan perannya dengan efektif, yaitu kompetensi teknis, kompetensi manajerial dan kemampuan mempengaruhi orang lain.

Supervisor dan guru saling membutuhkan dalam melaksanakan perannya masingmasing. Ini artinya berati bahwa guru seyogianya memahami apa yang diharapkan supervisor dan supervisor pun memahami apa yang diharapkan guru dari padanya. Terkait dengan pengembangan program supervisi pendidikan Biologi, maka perlu ditumbuhkan komitmen kepada supervisor dan guru bahwa perbaikan mutu proses dan hasil pembelajaran seyogianya dilaksanakan terus menerus dan berkesinambungan, serta setiap saat ada niat untuk memperbaikinya (pembiasaan).

Pemberdayaan akuntabilitas profesionalisme guru akan berkembang apabila didukung oleh oleh penciptaan budaya sekolah sebagai organisasi belajar, yaitu penciptaan kondisi institusi dimana para anggotanya menunjukkan kepekaan terhadap kekuatan, kelemahan, peluang dan tantangan yang dihadapi dan berupaya untuk menentukan posisi strategis untuk pengembangan lembaga.

Gugus-gugus kendali mutu (MGMP, PKG, KKKS, KKPS) dengan memberikan layanan terbaik sesuai dengan fungsi dan perannya masing-masing akan meningkatkan kualitas PBM Biologi di sekolah. Kelompok masyarakat sebagai mitra sekolah dan sebagai stakeholder tetap trus memberikan dukungan, baik moril maupun materil serta tetap menjalankan fungsi kontrolnya terhadap kinerja sekolah. Dukungan dari para pengambil 
kebijakan di daerah (Bupati, Walikota, Kepala Dinas, dll) dalam upaya meningkatkan layanan PBM, seperti penyediaan buku-buku pelajaran Biologi, alat peraga, dan sarana laboratorium dengan dukungan dana yang memadai serta pengiriman guru untuk mengikut penataran, seminar dan atau melakukan penelitian tindakan kelas.

\section{Sumber Bacaan:}

Deden NK. (2003). Strategi Pemberdayaan Peranserta Orang tua dan Masyarakat dalam Progran Sekolah. Disertasi, tidak dipublikasikan. Bandung : PPS UPI Bandung.

Herawan, D. (2004). Pengembangan Model Supervisi Akademik Mata Pelajaran IPA (Biologi) di SMU (Efektivitas Model Inovasi Supervisi Akademik Mata Pelajaran Biologi dalam Upaya Meningkatkan Kinerja Guru IPA/ Biologi di SMU). Disertasi, tidak dipublikasikan. Bandung : PPS UPI Bandung.

Paratama, Y. (2001). Pengembangan Model Sosialisasi Inovasi dan Supervisi Pembelajaran Ilmu Pengetahuan Alam (Studi Kualitatif pada Sekolah Lanjutan Tingkat Pertama SeKota Gorontalo). Disertasi. Tidak Dipublikasi. Bandung : PPS UPI Bandung

Siregar, N. (1999). Pedagogi Materi Subyek. Hand Out. Bandung : PPS UPI Bandung.

Satori, D. (1989). Pengembangan Model Supervisi Sekolah Dasar (Penelitian terhadap Efektivitas Sistem Pelayanan/Bantuan Profesional Bagi Guru SD di Cianjur, Jawa Barat). Disertasi. Tidak Dipublikasi. Bandung : PPS UPI Bandung 